\title{
Assessment of statistical models describing individual and group response of pigs to threonine intake*
}

\author{
J. Heger ${ }^{1,4}$, L. Křrižová ${ }^{2,5}$, M. Šustala ${ }^{2}$, S. Nitrayová ${ }^{1}$, P. Patráš ${ }^{1}$ \\ and D. Hampel ${ }^{3}$
}

\author{
${ }^{1}$ Research Institute of Animal Production, Slovak Centre of Agricultural Research \\ 949-92 Nitra, Slovakia \\ ${ }^{2}$ Research Institute of Animal Nutrition \\ 691-23 Pohořelice, Czech Republic \\ ${ }^{3}$ Central Institute for Supervising and Testing in Agriculture \\ Brno, Czech Republic
}

(Received 20 April 2007; revised version 8 June 2007; accepted 6 September 2007)

\begin{abstract}
A nitrogen balance experiment was conducted to study the individual and group response of growing pigs to threonine (Thr) intake. A series of fifteen purified diets with increasing concentration of Thr was fed sequentially to nine pigs during a 15-d experimental period. The concentration of Thr ranged from 50 to $140 \%$ of its assumed requirement while other essential amino acids were given in a $25 \%$ excess. $\mathrm{N}$ retention was related to Thr intake using rectilinear and curvilinear models. The quadratic-plateau model fitted the individual data significantly better $(\mathrm{P}=0.02)$ than the linear-plateau model. The $\mathrm{R}^{2}$ statistic indicated that the group response of pigs to Thr intake was better described by the linear-plateau and quadratic-plateau models than by exponential, saturation kinetics or four-parameter logistic models. Significant differences $(\mathrm{P}=0.004)$ were found between individual plateau values in the linear-plateau model while the slopes of the regression lines did not differ. No significant correlation was found between the slope and plateau or breakpoint values of the linear-plateau model. Marginal efficiency of Thr utilization derived from the linear-plateau model was 0.67 . In the quadratic-plateau model, marginal efficiency of Thr utilization was dependent on Thr intake and ranged from 0.77 (50\% of requirement) to 0.42 (100\% of requirement). Based on linear-plateau and quadratic-plateau models, daily requirement of $\mathrm{Thr}$ for a $45 \mathrm{~kg}$ pig was calculated to be 11.5 and $12.1 \mathrm{~g}$, respectively.
\end{abstract}

KEY WORDS: pigs, threonine, individual response, efficiency of utilization, requirement

\footnotetext{
* Supported by Science and Technology Assistance Agency of the Slovak Republic, Grant No. APVT-27-030802 and Grant Agency of the Czech Republic, Grant No. 523/00/0292

${ }^{4}$ Corresponding author: e-mail: jheger@tiscali.cz

${ }^{5}$ Present address: Research Institute of Cattle Breeding, 691-23 Pohořelice, Czech Republic
} 


\section{INTRODUCTION}

It is generally assumed that the response of a population to the increments of a limiting nutrient is inevitably curvilinear owing to the variability of individual animals in their production potential (plateau value) as well as maintenance requirement (abscissa intercept) (Fisher et al., 1973; Morris, 1999). Experiments studying the dose-response relationships in pigs fed diets providing a broad range of amino acid intake showed that the group response diminished as the limiting amino acid intake approached requirement (Gahl et al., 1994; King et al., 2000). Whether the response of individuals is rectilinear or curvilinear is not clear. The Reading model proposed by Fisher et al. (1973) for laying hens was based on an assumption that the individual animals respond linearly to limiting amino acid input below the requirement with no response above the requirement, implying a constant efficiency of amino acid utilization at suboptimal levels of intake. This concept has been widely used in mathematical models simulating pig growth (Whittemore, 1995; Sandberg et al., 2005a) or in models for estimating amino acid requirements (NRC, 1998). To date, the experimental data on individual response of pigs are scarce. Fuller and Garthwaite (1993), relating $\mathrm{N}$ retention to six levels of dietary protein, found that curvilinear models fitted the experimental data significantly better than the rectilinear model. In our recent experiments (Heger et al., 2007), we found that the individual response of pigs to fifteen levels of sulphur amino acids (methionine:cystine 1:1.13) followed a diminishing returns pattern while the relationship between $\mathrm{N}$ retention and methionine intake in the presence of excess cystine was clearly rectilinear. These results suggest that the form of response to various amino acids need not be the same. Since the estimation of amino acid requirements based on broken-line regression analysis is strongly dependent on the shape of the ascending part of the response, the correct description of the dose-response relationship is of considerable practical importance. Therefore, the aim of the present study was to examine the individual and group response of pigs to threonine intake. A method of consecutive 24-h N balances in response to small increments of the limiting amino acid (Heger et al., 2007) was used.

\section{MATERIAL AND METHODS}

\section{Animals and procedures}

The experimental procedures were reviewed and approved by the Animal Care Committee of the Research Institute of Animal Production. Nine female pigs from Large White boars and Large White $\mathrm{x}$ Landrace sows were used. Their 
mean initial body weight was 39.7 (SE 1.3) $\mathrm{kg}$. Before the start of the experiment, the animals were kept in metabolism cages for $7 \mathrm{~d}$. For the first $3 \mathrm{~d}$ of adaptation, they were fed on a common grower diet, while experimental diet with the lowest concentration of threonine was offered on days 4-7. The last day of the adaptation period, the pigs were fitted with bladder catheters draining into tared bottles containing $75 \mathrm{ml}$ of $3.5 \mathrm{M}-\mathrm{HCl}$. During the 15-d experimental period, fifteen diets with increasing concentration of threonine were fed sequentially to each pig. Urine was collected daily at $8.00 \mathrm{~h}$ starting on day 2 of the experimental period. From each 24-h collection period, aliquots were taken and analysed immediately for total N. Faeces were collected daily by frequent grab sampling, freeze-dried, and finely ground for subsequent analysis of $\mathrm{N}$ and $\mathrm{Cr}_{2} \mathrm{O}_{3}$. Based on the mean transit time of digesta (96 h) estimated previously (Heger et al., 2007), faeces were collected starting on day 5 of the experiment for subsequent 15 days. Body weights were recorded weekly.

\section{Diets and feeding}

Fifteen semipurified diets (Table 1) were formulated in which the concentration of threonine and of total $\mathrm{N}$ ranged from 3.81 and 11.20 to 10.62 and $31.26 \mathrm{~g} /$ $\mathrm{kg}$, respectively. The dietary level of threonine corresponded to $50-140 \%$ of its assumed requirement. The concentrations of other essential amino acids were $25 \%$ higher and their proportions were in accordance with ideal protein pattern as given by NRC (1998). The formulation of diets was based on daily true digestible amino acid requirements for a $48-\mathrm{kg}$ gilt with a mean daily carcass lean gain of $360 \mathrm{~g} / \mathrm{d}$ (NRC, 1998) and the daily feed intake of $90 \mathrm{~g} / \mathrm{kg}^{0.75}$. The pigs were fed twice daily at 06.00 and $14.30 \mathrm{~h}$ in two equal meals at a daily rate of $90 \mathrm{~g} / \mathrm{kg}^{0.75}$. Feed allowances were adjusted daily based on extrapolated body weights. Water was provided ad libitum.

With regard to very short balance periods and the possibility of not completely attaining a steady state in $\mathrm{N}$ metabolism within $24 \mathrm{~h}$, a preliminary experiment was carried out on five pigs (mean BW $49.1 \mathrm{~kg}$ ) to estimate the carry-over in urinary $\mathrm{N}$ excretion. A similar methodology as in the main experiment was applied. During the first five days, diets 10-14 were fed successively followed by diet 15 for the next five days. Daily urinary $\mathrm{N}$ excretion was measured as the criterion of response. 


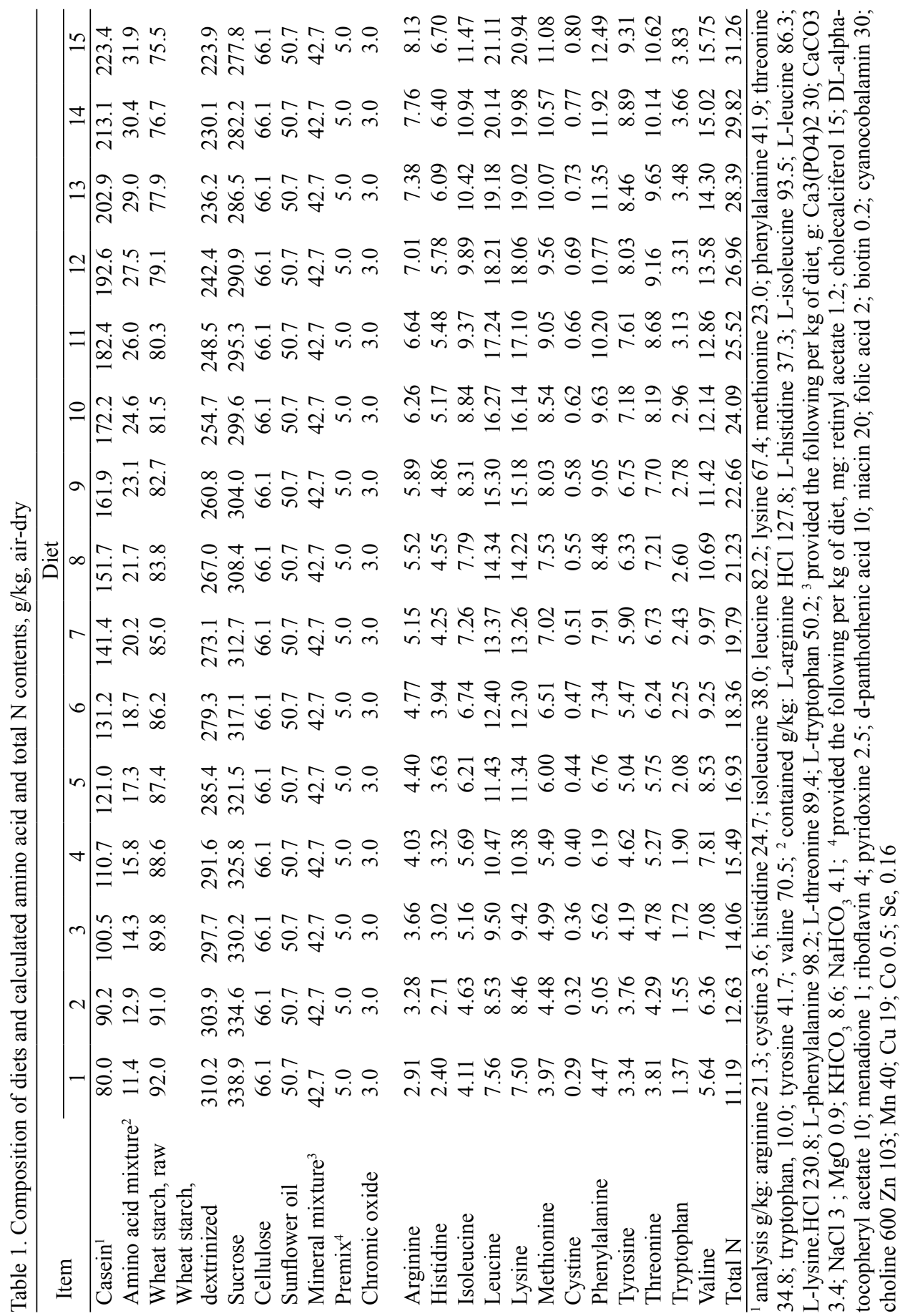




\section{Chemical analyses}

The amino acid composition of casein was analysed by ion-exchange chromatography (Llames and Fontaine, 1994), the $\mathrm{Cr}_{2} \mathrm{O}_{3}$ content of diets and faeces by atomic absorption spectrometry (Williams et al., 1962) and total $\mathrm{N}$ of the diets, faeces and urine by macro-Kjeldahl methodology (AOAC, 1984).

\section{Calculations and statistical analysis}

In the preliminary experiment, the carry-over of urinary $\mathrm{N}$ excretion was calculated as the difference between the mean plateau value on days 7-10 and $\mathrm{N}$ excretion on day 6 predicted using a linear regression equation. In the main experiment, daily $\mathrm{N}$ retention was calculated as $\mathrm{N}$ intake at day (i) minus urinary $\mathrm{N}$ losses at day $(\mathrm{i}+1)$ and faecal $\mathrm{N}$ losses at day $(\mathrm{i}+5)$. Faecal $\mathrm{N}$ excretion was estimated by the indicator method. From $\mathrm{N}$ retention, the retention of threonine was calculated based on the assumption that threonine represents $24.4 \%$ of $\mathrm{N}$ retained (Mahan and Shields, 1998). To eliminate the effect of body weight, all data were converted to units per $\mathrm{kg}^{0.75}$. Body weight for each day was interpolated from weekly weighings. Marginal efficiency of threonine utilization was calculated as the proportion of absorbed threonine retained as body protein. It was assumed that the true amino acid digestibility of experimental diets was $100 \%$.

To examine the response of $\mathrm{N}$ retention to threonine intake, linear-plateau and quadratic-plateau models were fitted to data for individual pigs as well as for all pigs using the NLIN procedure of SAS (Statistical Analysis Systems Statistical Package Ver. 8, SAS Institute, Cary, NC). The linear-plateau model describes the response (NR, $\mathrm{N}$ retention) in relation to dose (I, threonine intake) by a pair of equations

$$
\mathrm{NR}=\mathrm{b}_{0}+\mathrm{b}_{1} \mathrm{I} \text { when } \mathrm{I} \leq \mathrm{I}_{0} \text { and } \mathrm{NR}=\mathrm{NR}_{\mathrm{p}} \text { when } \mathrm{I} \geq \mathrm{I}_{0}
$$

where: $\mathrm{NR}_{\mathrm{p}}$ is the plateau and $\mathrm{I}_{0}$ is the dose corresponding to the breakpoint in the response. The ascending part of the quadratic-plateau model is described by the equation

$$
\mathrm{NR}=\mathrm{b}_{0}+\mathrm{b}_{1} \mathrm{I}+\mathrm{b}_{2} \mathrm{I}^{2}
$$

The closeness of fit of both models was assessed by a pair-wise comparison of residual mean squares (RMS) for each pig by Wilcoxon signed-rank test. The plateau values within each model were subjected to ANOVA and when significant value for treatment effect $(\mathrm{P}<0.05)$ was observed, the differences between means were evaluated using Fisher's LSD procedure. The significance of differences 
between the breakpoints in the response were evaluated by the paired t-test. Statgraphic Plus package (version 3.1, Statistical Graphic Corp., Rockville, MD, USA) was used to test the significance of differences among the slopes in the linear-plateau model. Correlation coefficients were calculated to asses the relations between the slope and plateau values in the linear model. In addition to the linearplateau and quadratic-plateau models, exponential, saturation kinetics (Mercer et al., 1978) and four-parameter logistic (Gahl et al., 1991) models were fitted to the sets of all data from each experiment using the NLIN procedure of SAS. The models are defined as follows:

exponential: $\quad \mathrm{NR}=\mathrm{NR}_{\max }-\mathrm{bc}^{-\mathrm{I}}$

saturation kinetics: $\quad \mathrm{NR}=\left(\mathrm{bk}+\mathrm{NR}_{\max } \mathrm{I}^{\mathrm{n}}\right) /\left(\mathrm{k}+\mathrm{I}^{\mathrm{n}}\right)$

four-parameter logistic: $\mathrm{NR}=\left(\mathrm{NR}_{\max }+\left[\mathrm{b}(1+\mathrm{c})-\mathrm{NR}_{\max }\right] \mathrm{e}^{-\mathrm{kl}}\right) /\left(1+\mathrm{ce}^{-\mathrm{kI}}\right)$

where: $\mathrm{NR}_{\max }$ is the maximum response (upper asymptote) and $\mathrm{b}, \mathrm{c}, \mathrm{k}$ and $\mathrm{n}$ are constants. The goodness of fit of the models was evaluated by means of R-squared statistic.

\section{RESULTS}

\section{Preliminary experiment}

Mean daily urinary $\mathrm{N}$ excretion during the experiment is shown in Figure 1.

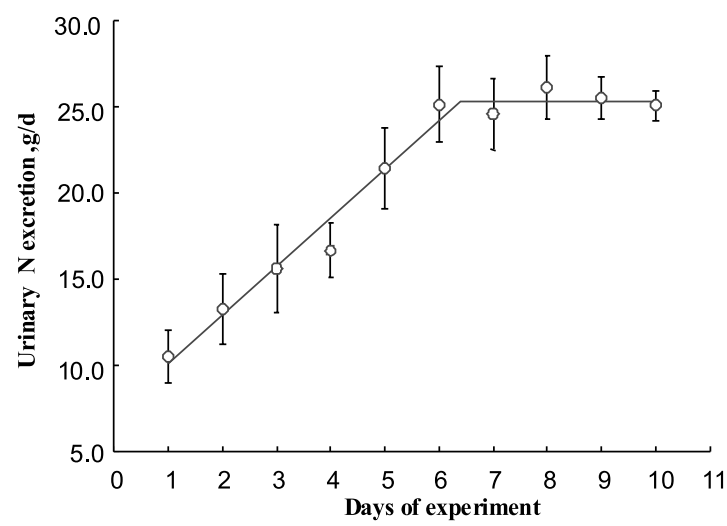

Figure 1. Urinary $\mathrm{N}$ excretion during the preliminary experiment. Points are means of five pigs with vertical bars indicating standard errors. Lines are plotted from equations: $y=2.82+7.25 x$ (day 1-6) and $\mathrm{y}=25.08$ (day 7-10) 
The ascending part of the response was described by an equation $\mathrm{y}=2.82+7.25 \mathrm{x}$ and the mean plateau value was 25.08 . The difference between the predicted response on day 6 and the mean plateau value (days 7 to 10) was 0.94 g, i.e. approximately $3.8 \%$ of total urinary $\mathrm{N}$ excretion on day 6 . As a result of this carry-over effect, mean daily $\mathrm{N}$ retention on day $6(23.7 \mathrm{~g})$ was overestimated by $3.9 \%$.

\section{Main experiment}

All animals were in good health and consumed their daily feed allowances. In most cases, the feed wastage was less than $1.5 \%$. The mean body weight of pigs during the $15-\mathrm{d}$ balance period increased from 39.7 to $51.5 \mathrm{~kg}$, resulting in daily body weight gain of $787 \mathrm{~g}$.

Mean data on threonine intake and $\mathrm{N}$ utilization are summarized in Table 2. The parameters of the linear-plateau and quadratic-plateau models as well as the breakpoint and plateau values are given in Table 3 . The $\mathrm{R}^{2}$ values for individual

Table 2. Mean data on $\mathrm{N}$ metabolism in pigs fed graded levels of threonine, $\mathrm{g} / \mathrm{kg}^{0.75}$

\begin{tabular}{cccccc}
\hline Diet & $\begin{array}{c}\text { Threonine } \\
\text { intake }\end{array}$ & $\begin{array}{c}\mathrm{N} \\
\text { intake }\end{array}$ & $\begin{array}{c}\text { Urinary } \\
\mathrm{N}\end{array}$ & $\begin{array}{c}\text { Faecal } \\
\mathrm{N}\end{array}$ & $\begin{array}{c}\mathrm{N} \\
\text { retention }\end{array}$ \\
\hline 1 & 0.279 & 0.887 & 0.186 & 0.148 & 0.553 \\
2 & 0.309 & 0.977 & 0.161 & 0.146 & 0.671 \\
3 & 0.338 & 1.066 & 0.152 & 0.141 & 0.774 \\
4 & 0.375 & 1.180 & 0.155 & 0.138 & 0.888 \\
5 & 0.431 & 1.350 & 0.159 & 0.137 & 1.055 \\
6 & 0.469 & 1.463 & 0.190 & 0.137 & 1.136 \\
7 & 0.503 & 1.566 & 0.194 & 0.140 & 1.231 \\
8 & 0.539 & 1.673 & 0.199 & 0.145 & 1.329 \\
9 & 0.567 & 1.758 & 0.218 & 0.146 & 1.395 \\
10 & 0.602 & 1.863 & 0.242 & 0.145 & 1.476 \\
11 & 0.640 & 1.977 & 0.308 & 0.136 & 1.534 \\
12 & 0.691 & 2.130 & 0.332 & 0.136 & 1.662 \\
13 & 0.718 & 2.212 & 0.350 & 0.144 & 1.718 \\
14 & 0.756 & 2.323 & 0.542 & 0.150 & 1.630 \\
15 & 0.783 & 2.397 & 0.677 & 0.152 & 1.569 \\
Pooled SEM & 0.006 & 0.021 & 0.023 & 0.006 & 0.031 \\
\hline
\end{tabular}

pigs ranged between 95.7 and 99.7, thus indicating that both models fitted the experimental data well. In general, the quadratic-plateau model provided higher $\mathrm{R}^{2}$ values than the linear-plateau model. Wilcoxon signed-rank test demonstrated that the former model fitted the data significantly better $(\mathrm{P}=0.024)$ than the latter one. The individual dose-response relationships represented by the best-fit lines for both models are shown in Figures 2 and 3. Except for pig No. 3, the slopes of regression lines fitted to the ascending part of the response were similar. Statistical 
Table 3. Parameters of linear-plateau and quadratic-plateau models relating $\mathrm{N}$ retention (NR) to threonine intake $(\mathrm{I})$ and calculated breakpoint $\left(\mathrm{I}_{0}\right)$ and plateau $\left(\mathrm{NR}_{\mathrm{p}}\right)$ values

\begin{tabular}{|c|c|c|c|c|c|c|c|c|c|c|c|}
\hline \multirow[b]{2}{*}{ Pig } & \multicolumn{5}{|c|}{ Linear-plateau $^{1}$} & \multicolumn{6}{|c|}{ Quadratic-plateau ${ }^{2}$} \\
\hline & $\mathrm{b}_{\mathrm{b}}$ & $\mathrm{b}_{1}$ & $\mathrm{I}_{0}$ & $\mathrm{NR}$ & $\mathrm{R}^{2}$ & $\mathrm{~b}_{0}$ & $b_{1}$ & $\mathrm{~b}_{2}$ & $\mathrm{I}_{0}$ & $\mathrm{NR}_{\mathrm{n}}$ & $\mathrm{R}^{2}$ \\
\hline 1 & -0.260 & 3.003 & 0.605 & $1.558^{\mathrm{ab}}$ & 97.5 & -0.856 & 5.980 & -3.507 & 0.674 & 0.605 & 98 \\
\hline 2 & & 2 & O & 1.5 & & & & -3 & & & \\
\hline 3 & 0 & 2.118 & 0.679 & $1.452^{\mathrm{a}}$ & 97.6 & -0.370 & 3.820 & -1.779 & 0.737 & 0.679 & \\
\hline 4 & -0.291 & 2.989 & 0.672 & $1.716^{\mathrm{cd}}$ & 97.9 & -0.5 & 4.135 & -1.285 & 0.692 & 0.672 & \\
\hline 5 & -0 & 2.826 & 0.68 & $1.763^{\mathrm{d}}$ & 98 & -0.3 & 3.395 & -0.606 & 0.693 & 0.687 & 98 \\
\hline 6 & -0 & 2.756 & 0.6 & $1.721^{\mathrm{cd}}$ & 98 & -0 & 4.815 & -2.251 & 0.692 & 59 & \\
\hline 7 & & 2.855 & & 1 & 97 & & 5.3 & -2.719 & 0.732 & & 99 \\
\hline 8 & -0.093 & 2.593 & & $1.668^{\text {bcd }}$ & 99 & & & -1.179 & 0.696 & & 99 \\
\hline 9 & -0.229 & 2.845 & 0.656 & $1.637^{\mathrm{bcd}}$ & 97.2 & -0.649 & 4.841 & -2.242 & 0.722 & 0.656 & \\
\hline All & -0.157 & 2.728 & 0.662 & 1.649 & 96.8 & -0.561 & 4.612 & -2.063 & 0.697 & 1.652 & 97. \\
\hline
\end{tabular}

abcd means within a column followed by different superscript differ significantly $(\mathrm{P}<0.05)$

${ }^{1} \mathrm{NR}=\mathrm{b}_{0}+\mathrm{b}_{1} \mathrm{I}$ when $\mathrm{I}<\mathrm{I}_{0}$ and $\mathrm{NR}=\mathrm{NR}_{\mathrm{p}}$ when $\mathrm{I}>\mathrm{I}_{0}$

${ }^{2} \mathrm{NR}=\mathrm{b}_{0}+\mathrm{b}_{1} \mathrm{I}+\mathrm{b}_{2} \mathrm{I}^{2}$ when $\mathrm{I}<\mathrm{I}_{0}$ and $\mathrm{NR}=\mathrm{NR}_{\mathrm{p}}$ when $\mathrm{I}>\mathrm{I}_{0}$

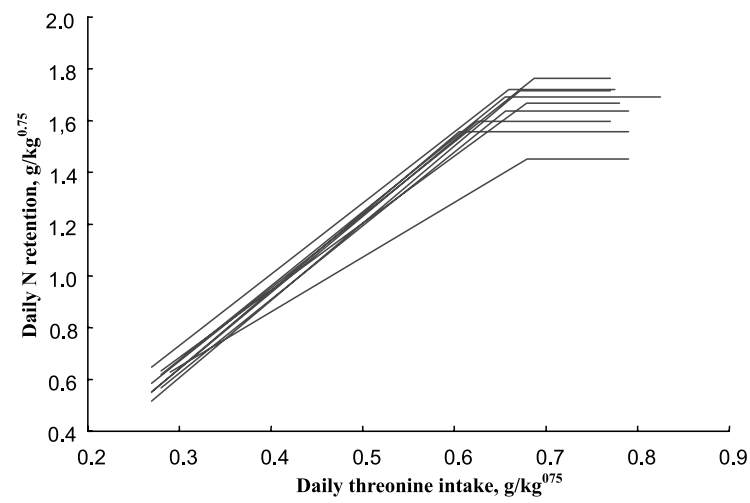

Figure 2. Nitrogen retention in pigs in relation to threonine intake. The lines are best fits for individual animals using the linear-plateau model

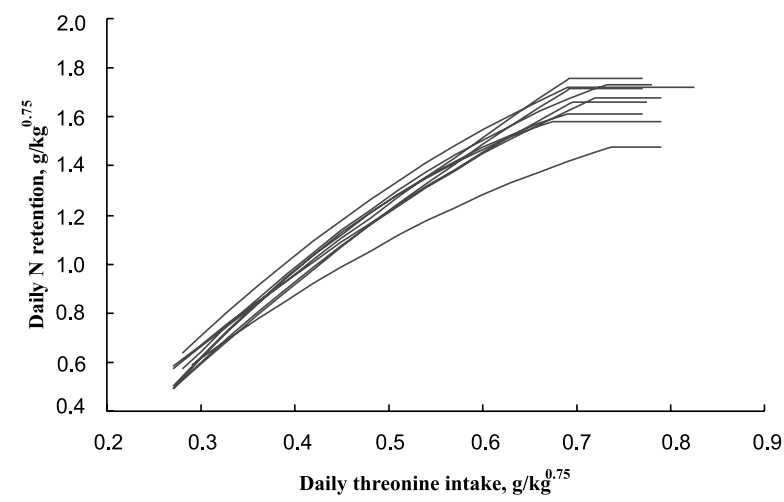

Figure 3. Nitrogen retention in pigs in relation to threonine intake. The lines are best fits for individual animals using the quadratic-plateau model 
analysis of the linear-plateau model (including pig No. 3) revealed that the slopes of regression lines were not different $(\mathrm{P}=0.11)$. In contrast, there were significant differences in plateau values estimated by the linear-plateau model $(\mathrm{P}=0.004)$ and the plateaus in the quadratic-plateau model tended to differ $(\mathrm{P}=0.095)$. Again, the lowest plateau value was found for pig No. 3. The breakpoins found in the quadratic-plateau model were significantly higher $(\mathrm{P}=0.001)$ than those in the linear-plateau model. No significant correlation was found between the slopes of regression lines and plateau or breakpoint values.

The parameters of asymptotic models fitted to data sets for all pigs are summarized in Table 4. The closeness of fit of all models was similar, the four-

Table 4. Parameters of asymptotic models relating $\mathrm{N}$ retention (NR) to threonine intake (I) as fitted to all pigs

\begin{tabular}{lccccccc}
\hline Model & $\mathrm{NR}_{\max }$ & $\mathrm{b}$ & $\mathrm{c}$ & $\mathrm{k}$ & $\mathrm{n}$ & $\mathrm{RMS}$ & $\mathrm{R}^{2}$ \\
\hline Exponential $^{1}$ & 2.097 & 3.339 & 15.321 & & & 0.00812 & 94.3 \\
Saturation kinetics $^{2}$ & 1.870 & 0.357 & & 0.057 & 3.610 & 0.00780 & 94.6 \\
Four-parameter logistic $^{3}$ & 1.763 & 0.163 & 19.339 & 7.540 & & 0.00770 & 94.7 \\
\hline
\end{tabular}

${ }^{1} \mathrm{NR}=\mathrm{NR}_{\max }-\mathrm{bc}^{-1}$

${ }^{2} \mathrm{NR}=\left(\mathrm{bk}+\mathrm{NR}_{\max } \mathrm{I}^{\mathrm{n}}\right) /\left(\mathrm{k}+\mathrm{I}^{\mathrm{n}}\right)$

${ }^{3} \mathrm{NR}=\left(\mathrm{NR}_{\max }+\left[\mathrm{b}(1+\mathrm{c})-\mathrm{NR}_{\max }\right] \mathrm{e}^{-\mathrm{kl}}\right) /\left(1+\mathrm{ce}^{-\mathrm{kl}}\right)$

parameter logistic and saturation kinetics models giving slightly better fit than the simple exponential model. The comparison of $\mathrm{R}^{2}$ values including those for the linear-plateau and quadratic-plateau models (Table 3, all pigs) showed that the quadratic-plateau model fitted the experimental data better than any other model.

\section{DISCUSSION}

The results of the preliminary experiment suggested that the adaptation of pigs to the increasing $\mathrm{N}$ intake was not complete within $24 \mathrm{~h}$, a part of catabolized $\mathrm{N}$ being excreted via urine later. However, the estimated carry-over effect on total urinary $\mathrm{N}$ excretion or $\mathrm{N}$ retention was small. A model calculation applying the present carry-over data to a similarly designed experiment with sulphur amino acids (Heger et al., 2007) showed that, as a result of incomplete urinary $\mathrm{N}$ excretion, the slope of regression line relating $\mathrm{N}$ retention to sulphur amino acid intake increased by $3.8 \%$. By contrast, both plateau and breakpoint values remained essentially unchanged. Whether or not the relative carry-over effect is the same across the whole range of threonine intake is not clear. In the preliminary experiment, the pattern of urinary $\mathrm{N}$ excretion was studied at $\mathrm{N}$ intakes near requirement. It is possible that the carry-over effect may decrease with decreasing $\mathrm{N}$ intake which would manifest itself by a more pronounced curvature of the ascending part of the 
response. With respect to this uncertainty and a small effect on $\mathrm{N}$ retention, no correction of present data for carry-over effect was made.

The comparison of linear-plateau and quadratic-plateau models for individual pigs showed that the latter model fitted the data sets in all animals better than the former one. Even though the $\mathrm{R}^{2}$ values were quite similar in some pigs, the Wilcoxon signed-rank test indicated that the difference between both models was significant. This is in agreement with our previous study with sulphur amino acids (Heger et al., 2007). In addition, Fuller and Garthwaite (1993) demonstrated that the response of $\mathrm{N}$ retention to $\mathrm{N}$ intake in individual pigs was better described by curvilinear models than by the rectilinear model. On the other hand, a rectilinear response was found in pigs fed graded levels of methionine with excess cystine (Heger et al., 2007). It was speculated that this might be due to the sparing effect of cystine on methionine utilization (Heger et al., 2007), but the possibility that pigs respond differently to intake of different amino acids cannot be excluded.

The $\mathrm{R}^{2}$ values for exponential, saturation kinetics and four-parameter logistic models fitted to pooled data for all pigs (Table 4) were similar and the goodness of fit of neither of these models was better than that of the linear-plateau or quadraticplateau models (Table 3, all pigs). It seems that, at least in the limited range of threonine intake studied, the asymptotic models offer no advantage over the simpler breakpoint models in describing the group response to threonine intake. A definite advantage of the breakpoint models is that they provide a clear-cut estimate of the requirement. In the present study, mean threonine requirements estimated by the linear-plateau and quadratic-plateau models were 0.662 and $0.697 \mathrm{~g} / \mathrm{kg}^{0.75}$, respectively. These values corresponded to daily threonine intake of 11.5 and 12.1 $\mathrm{g}$, respectively, for a $45 \mathrm{~kg}$ pig. Threonine requirement for a similar pig depositing daily $179 \mathrm{~g}$ protein $\left(1.65 \mathrm{~g} / \mathrm{kg}^{0.75}\right)$ calculated using the NRC (1998) model was considerably higher, amounting to $13.85 \mathrm{~g}$ per day. This discrepancy might be due to the overestimation of $\mathrm{N}$ retention frequently seen in experiments based on a classical N-balance technique (Möhn et al., 2000). As the rectilinear models usually underestimate the dose at which the response is maximized (Morris, 1999), the breakpoint value of the quadratic-plateau model seems to be a more objective estimate of the requirement (Baker, 2003; Heger et al., 2007).

The differences between the plateau values in both the linear-plateau and quadratic-plateau model indicate that the maximum protein deposition rate may vary considerably even in clinically healthy pigs of the same genotype (Figures 2 and 3). Similarly, the slopes of individual regression lines tended to differ but the correlation between the two variables was weak $(\mathrm{r}=0.55 ; \mathrm{P}=0.12)$ suggesting that the attainment of a high protein accretion need not be related to high efficiency of amino acid utilization. The results of other experiments are inconsistent. In our preceding study (Heger et al., 2007), a significant positive correlation between the slope and plateau values was observed in one experiment while in another one 
an insignificant negative correlation was found. Moehn et al. (2004) reported a decreased lysine catabolism with increasing protein deposition rate, thus indicating a positive relation between the efficiency of lysine utilization and pig performance potential.

The form of response and choice of input data had a strong impact on the marginal efficiency of threonine utilization. In the linear-plateau model, the mean efficiency of utilization was 0.67 . The efficiency values derived from the quadratic-plateau model were dependent on the level of threonine intake relative to requirement. As threonine intake increased from 50 to $100 \%$ of the estimated requirement, the marginal efficiency of threonine utilization decreased from 0.77 to 0.42 . The efficiency value calculated from data taken from the lower half of the ascending part of the response was 0.69 , which was similar to the value of 0.67 derived from the linear-plateau model. In contrast, the efficiency of utilization representing the upper half of the suboptimal threonine intake was only 0.51 . The experiments by de Lange et al. (2001) also suggest that the efficiency of threonine utilization is not constant within the whole range of suboptimal threonine intake. Using a serial slaughter technique, de Lange et al. (2001) found that the efficiency of threonine utilization above maintenance increased significantly as threonine intake decreased from 70 to $60 \%$ of requirement. The efficiency values calculated from $\mathrm{N}$ balance data showed a linear increase as threonine intake decreased from 100 to $60 \%$ of requirement. The quantitative data on the efficiency of threonine utilization are scarce. Adeola (1995) and Ferguson et al. (2000) reported values of 0.60 and 0.59 , respectively. Based on threonine intake levels showing a linear dose-response relationship, de Lange et al. (2001) estimated the efficiency of threonine utilization to be 0.73 . In the above described experiments, the lowest threonine intake met or exceeded $50 \%$ of requirement. In contrast, a considerably higher efficiency $(0.83)$ was found in pigs when threonine intake ranged from zero to about $80 \%$ of requirement (Heger et al., 2003). This may serve as an indirect evidence of a curvilinear response of pigs to limiting amino acid intake. As pointed out by Sandberg et al. (2005b), the efficiency with which protein is retained is central to the prediction of the rates of both protein and lipid retention. A further research is needed to explore the effect of nutritional and environmental factors on the efficiency of limiting amino acid utilization in a greater detail.

\section{CONCLUSIONS}

The present results suggest that both the individual and group response of pigs to threonine intake are curvilinear at suboptimal levels of intake. Consequently, the marginal efficiency of threonine utilization diminishes as threonine intake approaches optimum. The variable efficiency of amino acid utilization should 
be taken into consideration in models predicting the rates of protein retention in response to protein supply.

\section{REFERENCES}

Adeola O., 1995. Dietary lysine and threonine utilization by young pigs: efficiency for carcass growth. Can. J. Anim. Sci. 75, 445-452

AOAC, 1984. Association of Official Analytical Chemists, Official Methods of Analysis. 14 Edition. Washington, DC

Baker D.H., 2003. Ideal amino acid patterns for broiler chicks. In: J.P.F. D’Mello (Editor). Amino Acids in Animal Nutrition. $2^{\text {nd }}$ Edition. CABI Publishing, Wallingford, pp. 223-235

de Lange C.F.M., Gillis A.M., Simpson G.J., 2001. Influence of threonine intake on whole-body protein deposition and threonine utilization in growing pigs fed purified diets. J. Anim. Sci. 79, 3087-3095

Ferguson N.S., Arnold G.A., Lavers G., Gous R.M., 2000. The response of growing pigs to amino acids as influenced by environmental temperature. 1. Threonine. Anim. Sci. 70, 287-297

Fisher C., Morris T.R., Jennings R.C., 1973. A model for the description and prediction of the response of laying hens to amino acid intake. Brit. Poultry Sci. 14, 469-484

Fuller M.F., Garthwaite P., 1993. The form of response of body protein accretion to dietary amino acid supply. J. Nutr. 123, 957-963

Gahl M.J., Crenshaw T.D., Benevenga N.J., 1994. Diminishing returns in weight, nitrogen and lysine gain of pigs fed six levels of lysine from three supplemental sources. J. Anim. Sci. 72, 3177-3187

Gahl M.J., Finke N.J., Benevenga N.J., Crenshaw T.D., 1991. Use of a four-parameter logistic equation to evaluate the response of growing rats to ten levels of each indispensable amino acid. J. Nutr. 121, 1721-1729

Heger J., Křížová L., Šustala M., Nitrayová S., Patráš P., Hampel, D., 2007. Individual response of growing pigs to sulphur amino acid intake. J. Anim. Physiol. Anim. Nutr. (in press)

Heger J., Phung T.V., Křížová L., 2002. Efficiency of amino acid utilization in the growing pig at suboptimal levels of intake: lysine, threonine, sulphur amino acids and tryptophan. J. Anim. Physiol. Anim. Nutr. 86, 153-165

King R.H., Campbell R.G., Smits R.J., Morley W.C., Ronnfeldt K., Butler K., Dunshea F.R., 2000. Interrelationship between dietary lysine, sex, and porcine somatotropin administration on growth performance and protein deposition in pigs between 80 and $120 \mathrm{~kg}$ live weight. J. Anim. Sci. $78,2639-2651$

Llames C.R., Fontaine J., 1994. Determination of amino acids in feeds: Collaborative study. J. AOAC Int. 77, 1362-1402

Mahan D.C., Shields R.G., 1998. Essential and nonessential amino acid composition of pigs from birth to 145 kilograms of body weight, and comparison to other studies. J. Anim. Sci. 76, 513-521

Mercer L.P., Flodin N.W., Morgan P.H., 1978. New methods for comparing the biological efficiency of alternate nutrient sources. J. Nutr. 108, 1244-1249

Moehn S., Ball R.O., Fuller M.F., Gillis A.M., de Lange C.F.M., 2004. Growth potential, but not body weight or moderate limitation of lysine, affects inevitable lysine catabolism in growing pigs. J. Nutr. 134, 2287-2292

Möhn S., Gillis A.M., Moughan P.J., de Lange C.F.M., 2000. Influence of dietary lysine and energy intakes on body protein deposition and lysine utilization in the growing pig. J. Anim. Sci. 78, $1510-1519$ 
Morris T.R., 1999. Experimental Design and Analysis in Animal Sciences. CABI Publishing, Wallingford, pp. 208

NRC, 1998. Nutrient Requirements of Swine. National Research Council. 10 $0^{\text {th }}$ Edition. National Academy Press. Washington, DC

Sandberg F.B., Emmans G.E., Kyriazakis I., 2005a. Partitioning of limiting protein and energy in the growing pig: description of the problem, possible rules and their qualitative evaluation. Brit. J. Nutr. 93, 205-212

Sandberg F.B., Emmans G.E., Kyriazakis I., 2005b. Partitioning of limiting protein and energy in the growing pig: testing quantitative rules against experimental data. Brit. J. Nutr. 93, 213-224

Whittemore C.T., 1995. Modelling the requirement of the young growing pig for dietary protein. Agr. Syst. 47, 415-425

Williams C.H., David D.J., Lismaa O., 1962. The determination of chromic oxide in faeces samples by atomic absorption spectrometry. J. Agr. Sci. 59, 381-385 